\title{
Enhancing Reading Comprehension through Translanguaging Strategy
}

\author{
Rafi'ah Nur \\ Universitas Muhammdiyah Parepare, Parepare, Indonesia \\ Zulwahyuni Namrullah \\ Universitas Muhammdiyah Parepare, Parepare, Indonesia \\ Syawal \\ Universitas Muhammdiyah Parepare, Parepare, Indonesia \\ Nasrullah A \\ Universitas Muhammdiyah Parepare, Parepare, Indonesia
}

\begin{abstract}
In the reading process, reading comprehension is an essential part. This concept is in line with the Minister of Education and Culture Regulation number 23 in 2015, about the literacy movements to build a good character. However, students sometimes could not achieve it because the student cannot comprehend the reading material well. Besides, most students seem complicated to understand an English text and lazy to find the appropriate strategy to elaborate on their reading comprehension in rural living areas. Those become some researchers' concerns to conduct this research when doing observations at SMP Negeri 4 Maiwa in Enrekang Regency South Sulawesi, Indonesia. The students showed feeble and problematic reading comprehension. Then, taking the benefit of the tongue's benefits, adapted the translanguaging strategy as problem-solving for students' lack of reading comprehension. The object of this study is whether or not the translanguaging strategy can enhance student reading comprehension of eight-grade students SMP Negeri 4 Maiwa. The researchers applied the quasi-experimental method, with two groups pre-test and post-test design. The samples of the research consisted of $\mathbf{3 5}$ students from two classes. The result of the data analysis showed that the students' reading comprehension improved significantly. It indicated that the translanguaging strategy could enhance the reading comprehension of the students at that school. The students who learned reading through the translanguaging strategy had better improvement than the students who learned through the translation strategy.
\end{abstract}

Index Terms - translanguaging, strategy, mother tongue, translation, reading comprehension

\section{INTRODUCTION}

People read because they need to know a piece of information according to their necessity. Reading is defined as a process to gain information related to someone's purpose through the written information that has been published by the writer (Grabe \& Stoller, 2013). The information can be easily found in printed or digital media, complete with translation of every language, for instance, into Indonesian or English itself. Technology development in the twentyfirst century had helped humans and led them to use the internet as digital information media frequently to find information easier than printed text. Reading source availability should be in line with people's interests and understanding. Unfortunately, some Indonesian cannot understand English literature, which makes them have less valuable education and contribution than other countries (Andrade, 2006). The minister of Education and Culture set out school literacy movements in its' regulation number 23 in 2015 and confirmed the growth of character through the reading process performed within 15 minutes each day (Kemendikbud, 2016). It means students' reading interest can improve by implementing school literacy movement routines in their daily school life. Reading any kind of book or information in Indonesian or English will become a student's reading experience. The world knowledge and word meaning influence student understanding, where the more students read and learn about the topic, the more comfortable the student is to understand the passage (Klingner, Vaughn, \& Boardman, 2015). Students' character as government goals also can be achieved by the teacher's role in the classroom by improving students' reading interest and comprehension.

Comprehending the reading material is an essential part of the reading activity. Meaning, learning, and pleasure are the ultimate learning goals to read (Klingner, Vaughn, \& Boardman, 2015). Teacher's roles are also important in the classroom during reading activity. Hence, the reading activity is not eligible without understanding the content by having a piece of basic knowledge, reading experience, and teacher's guidance to achieve reading for a purpose. 
As a multicultural country, Indonesia has different local languages in every region, especially in Sulawesi Selatan. There are four ethnicities dominate Sulawesi Selatan. They are Makassar, Bugis, Toraja, and Mandar, which have their mother tongue. Therefore, it is difficult for the indigenous to gain valuable education and information in other languages because they only understand their local language. According to García \& Wei (2014), the multilingual term refers to people in a group who use more than two languages, wherein Sulawesi Selatan; the mother tongue is a first language (L1) that learned by indigenous people from their forefathers, followed by the Indonesian as the second language (L2) also as a national language. Then, learning new languages like English becomes their third language (L3)

The research took place in a school of rural areas, known as SMP Negeri 4 Maiwa, in Enrekang district Indonesia, with a robust local mother tongue. After doing pre-observation to 36 students of two eighth-grade classes as total sampling, the researchers found that the student used their mother tongue mixed with the Indonesian language to communicate with each other in their home, school area, and even in English class. Another result found by giving the test of reading comprehension, where only $5.56 \%$ student can pass 75 minimum score based on the assessment criteria of the minimum standard of learning mastery that has been determined by SMP Negeri 4 Maiwa, according to the Department of Education No. 020/2007 about education assessment standard of Kurikulum Tingkat Satuan Pendidikan (KTSP). Meanwhile, there is $94.44 \%$ of students still below the score criteria.

After performing pre-observation to 36 students, the researchers found that student English reading comprehension still problematic. The test result shows that most of the students have a low capability to interpret the text given. Most of the students already found the text keywords based on the students' answer sheets, but they could not elaborate on the content of the text based on the questions provided. Moreover, according to the questionnaires, most students would easily understand the story or information in English when they were getting help from someone's instruction, the explanation from other students or teachers, translated text, and using their strategy. Meanwhile, using the dictionary to find the meaning was students' most strategy used before. It indicates that most of the students dependent on others. The students are challenging to be independent because of the inappropriate and unvaried strategies they used in the classroom.

The title of this research is enhancing the reading comprehension of the eighth-grade students of SMP Negeri 4 Maiwa through translanguaging strategy. The researchers chose to use the translanguaging strategy as an appropriate strategy to improve student reading comprehension collaborating with the teacher's role during the learning process.

Teacher's roles are needed during the student learning process, explaining and translating the material, and guiding them into a good understanding. Reading comprehension will be fulfilled by understanding the meaning, learning the content, and enjoying the reading. Translanguaging comes up with direct instruction, build an interaction to help students face their learning obstacles. The language practices use translanguaging in one linguistic unity as belonging to more than two separate languages (García \& Wei, 2014). Therefore, the teacher should actively control and manage the class with the interaction in the multilingual term based on teacher's and student's agreement in translanguaging.

The multilingual students are comfortable in using their mother tongue. By taking the mother tongue's benefit in the local area, the translanguaging strategy was efficient during the class. According to the second questionnaire, there were $51.35 \%$ who sometimes understand illustration using the mother tongue, $64.86 \%$ of students usually understand with text translated in the mother tongue, and $51.35 \%$ natural to interpret the text using mother tongue. The student seems to be more understandable when interacting in the mother tongue or local language. In other words, students would understand when their mother tongue was also used during the reading comprehension class to interpret the meaning in order to achieve reading goals. Therefore, the translanguaging strategy is an effective solution to be used in the learning process.

\section{TRANSLANGUIGING}

The strategy in teaching is an essential part of enhancing student understanding. The strategy is used to define as a set of abilities under the reader's awareness control, which commonly not as a natural of reading (Grabe and Stoller, 2013). Constructed by some definitions, the translanguaging strategy refers to a specific way to solve student learning obstacles in reading comprehension by learning to interpret the meaning of reading text independently. Translanguaging term originally comes from the Welsh, which Cen Williams used in 1994 to alternate languages for receptive to a bilingual school in Wales (García and Wei, 2014). Garcia and Wei (2014) state that translanguaging is a language practice that applies different language features against each other in one interaction. Translanguaging also helps to make a meaning using two or more languages in an integrated manner (Desmond and Makalela, 2013:88). Baker (2011:288) was the first translated translanguaging as 'the process of making meaning, shaping experience, obtaining understanding and knowledge through the use of two languages.'

A translanguaging is accurately adapted to facilitate inference-making strategies using the learners' mother tongue and English in the same classroom lesson. Translanguaging is also a way to reinforce students' bilingualism in using all of their languages as a resource for learning, reading, writing, and thinking in the classroom (Celic, 2012). Simultaneously using two languages might reflect the learners' identities in a positive light in the learning process, which could encourage them to consciously engage and take possession, resulting in more in-depth understanding and essential outcomes (Desmond and Makalela, 2013). It hopefully can help the student to face their learning difficulty, especially in a local area. To produce the different ways of multilingual speakers, create and interpret different kinds of 
linguistic signs to communicate across contexts and participants, and perform their different prejudices (García and Wei, 2014).

Students could better comprehend the complex texts when they access their background knowledge of other languages. (Otheguy, García, \& Reid (2015) claimed that translanguaging allows students to retrieve their full linguistic repertoire without being conscious always of socially and politically defined boundaries of named, national, and state languages. This flexible use of linguistic resources liberates linguistic minority students' voices, promotes deep and reflexive thinking, and enables rigorous cognitive engagement with texts (García and Wei, 2014). Translanguaging assigns that bilinguals have a single integrated linguistic repertoire from which they strategically draw appropriate features to communicate effectively. The translanguaging as a pedagogical approach results from the deliberate alternating input and output languages between the teacher and the learners to enhance understanding. In principle, translanguaging may refer to a process through which a teacher allows learners to formulate and share ideas using a needlepoint of vocabulary in their linguistic repertoire (Desmond and Makalela, 2013:89). It also allows a space for multilingual language learners to apply different scopes of their experiences and linguistic knowledge into one organized and meaningful performance.

Translating the meaning without background knowledge will be difficult for the reader to understand the meaning. Translanguaging significantly enhanced learners' ability to apply background knowledge when answering questions based on the English reading text (Desmond and Makalela, 2013). Therefore, translanguaging is in line with the component skill of reading comprehension to construct a better reading understanding. The ability to draw inferences of translanguaging also helps a reader understand complex and subtle implicit messages carried through the writer's choice of particular vocabulary. (Desmond and Makalela, 2013). Thus, they understand the meaning and know the explicit message by shaping a new inference.

As a strategy, translanguaging in reading allows every student to read any book in multiple languages to build student understanding. Celic (2012) allows her bilingual student to read thematically in multiple languages to process a new language by taking notes and discussing the reading material. The student can share their reading experience and opinion related to the reading text in both languages used. After doing extensive English reading, the student will be asked to find the other information in their native language, then draw the English reading inference into a new idea in their home language. In other words, translanguaging allows students to be independent in reading and writing to gain information.

Translanguaging is different from code-switching, code-mixing, and translation. Code-switching and code-mixing are well-known characters in the speech pattern of the average bilingual in any human society. Code-switching is a bilingual-mode activity in which more than one language, typically speakers' native language and second language (L2), are used as interference language (Park, 2012:50). Bokamba (1989) also posits that code-switching is the mixing of words, phrases, and sentences from two distinct grammatical or sub-systems across sentence boundaries within the same speech event. A code-mixing, meanwhile, is the embedding of various linguistic units such as affixes (bound morphemes), words (unbound morphemes), phrases, and clauses from a co-operative activity where the participants must reconcile what they hear with what they understand in order to infer what is intended (Ayeomoni, 2006).

Translanguaging differs from code-switching and code-mixing, which refers not merely to a shift or a shuttle between two languages. In translanguaging, however, the speakers' construct and use the original and sophisticated interrelated conversational practices that it cannot easily assign to one or another traditional definition of a language, but that makes up the speakers' complete language repertoire (García and Wei, 2014:22).

The process of code-switching, going back and forth from one language belonging to one grammatical system, has admitted much attention in the literature on bilingualism (Auer, 1999; Myers-Scotton, 1993 in Meteus, 2014:367). In code-switching, for instance, the student says: "I want to eat candy, tapi saya takut gigi saya rusak." The sentence shows that there is a switching language between English into Indonesian. Another example in code-mixing is the student saying: "I am sick, tapi do not cerita ke anyone" or "Ibu saya support semua activities yang I lakukan." The sentences clearly show the inserted words in a different language, which is called code. Every language has a different code but has the same meaning. A translanguaging approach is typical as "going back and forth from one language belonging to one grammatical system to another" (Mateus, 2014). Translanguaging uses a language repertoire as a whole, where there is no code-switching or even code-mixing in produce the sentence or language. In translanguaging, the students, who get utterance in English, will answer the question in different languages except for English, for instance, in Indonesian without any interference language or any other words inserted.

Translation has been typically employed to transfer written or spoken source language texts to equivalent written or spoken target language texts. The purpose of translation is to duplicate some kinds of texts such as religious text, literary, scientific, and philosophical texts in another language, making them available to more extensive readers (Ordudari, 2010). It also involved such as form, meaning, style, proverbs, and idioms. While translanguaging involves all the form needs in translation to shape a new idea with a different language. It is not adequate to only make meaning by changing or transferring the source language into a target language without interpreting its connotation. In translation, "I want to eat" will be translated into "Saya ingin makan," but in translanguaging, the sentence will mean in Bahasa Indonesia "Dia ingin makan, berarti dia sedang lapar." It indicates how translanguaging takes the learner to understand and learn to outline a notion from a source language into a target language by paying attention to the language manner. 
Every single strategy used has its purpose related to the study. A translanguaging theory in education views was integrating the students' full linguistic repertoire as merely the only way to develop language practices valued in school and education (García and Wei, 2014:74). A translanguaging is accurately adapted to facilitate inference-making strategies using the learners' mother tongue and English in the same classroom lesson. Simultaneously using two languages would possibly reflect the learners' identities in a positive light in the learning process, which could encourage them to consciously engage and take possession, resulting in more in-depth understanding and essential outcomes (Desmond and Makalela, 2013:89). It hopefully can help the student to face their learning difficulty, especially in a local area.

\section{METHOD}

The research on the use of translanguaging strategy to the English reading comprehension of students formulated the problem of the research into a simple question: "Do the implement of translanguaging strategy can enhance reading comprehension of eighth-grade students of SMP Negeri 4 Maiwa, Indonesia?" Based on the problem, the research objective, then, was to find out whether or not the translanguaging strategy can enhance reading comprehension of eighth-grade students of SMP Negeri 4 Maiwa.

The research population was the second-year students of SMP Negeri 4 Maiwa in the academic year 2017/2018. The total numbers of the population were 35 students. The sampling technique was total sampling because there were only two classes, VIII A and VIII B, with 35 students. To assign the experimental and control group, the researchers chose the class by implementing random sampling. Where VIII A was an experimental group, and VIII B was a control group.

Data collection was conducted from July to August 2018 by applying a reading comprehension test as the instrument. The reading comprehension test was in the form of a multiple-choice test, consisting of an Indonesian and English text with ten questions with the English or Indonesian. The researchers composed the questions by considering the material and reading technique that was learned by students. It involved the main idea, figures, topic sentence, historical events, and the text's moral message to answer the questions. The standard of competency and basic competence based on school determinate

This research applied a quasi-experimental design that applies the pretest-posttest control group design. The researchers used inferential statistics to conduct data analysis. The test of the hypothesis used a t-test with $\alpha=0.05$ level of significance for independent sample, the formula degrees of freedom is $\mathrm{df}=\mathrm{n} 1+\mathrm{n} 2-2$ (Gay, E. Mills, and Airasian, 2011). The formula of the statistical hypothesis in this research is two-tailed (Sugiyono, 2016). The researchers would accept the null hypothesis and reject the alternative hypotheses if the t-test calculation were lower to the t-table.

\section{FINDINGS AND DisCUSSION}

\section{A. Findings}

The findings present the result of the pre-test, the post-test result, and the result of inferential statistics.

The Rate Percentages Scores of Pre-test and Post-test of Experimental class and Control class

This part consists of the pre-test and the post-test rate percentages score for both experimental and control classes.

Pre-test

The result of the pre-test of students for the experimental class and control class were as follows:

TABLE 1

\begin{tabular}{|c|c|c|c|c|c|c|}
\hline \multirow{2}{*}{$\begin{array}{l}\text { Scale } \\
1-100\end{array}$} & \multirow{2}{*}{ Predicate } & \multirow{2}{*}{ Classification } & \multicolumn{2}{|c|}{ Experimental Class } & \multicolumn{2}{|c|}{ Control Class } \\
\hline & & & $\mathrm{F}$ & $\%$ & $\mathrm{~F}$ & $\%$ \\
\hline $96-100$ & A & \multirow{2}{*}{ Very good } & - & - & - & - \\
\hline $91-95$ & A- & & - & - & - & - \\
\hline $86-90$ & $\mathrm{~B}+$ & \multirow{3}{*}{ Good } & - & - & - & - \\
\hline $81-85$ & B & & - & - & - & - \\
\hline $75-80$ & B- & & - & - & - & - \\
\hline $70-74$ & $\mathrm{C}+$ & \multirow{3}{*}{ Fair } & - & - & - & - \\
\hline $65-69$ & $\mathrm{C}$ & & - & - & - & - \\
\hline $60-69$ & C- & & - & - & - & - \\
\hline $55-59$ & $\mathrm{D}+$ & \multirow{2}{*}{ Poor } & - & - & - & - \\
\hline \multirow[t]{2}{*}{$<55$} & D & & 17 & 100 & 18 & 100 \\
\hline & & & 17 & 100 & 18 & 100 \\
\hline
\end{tabular}


Table 1 shows the result of the conducted pre-test in both classes, categorized as a low classification score. The result was released before giving some treatment to students learning the process. The rating percentage of pre-test scores of the experimental and control classes was both in the same classification score. It means the reading comprehension of students is still problematic, where there were $100 \%$ of students who had low scores were categorized as poor achievement.

Post-test

The result of the post-test of students for the experimental class and control class were as follows:

TABLE 2

The PERcentage Scores ReAding Comprehension Of ExPerimental Class And Control Class In The Post-Test

\begin{tabular}{|lclllll|}
\hline Scale & Predicate & Classification & \multicolumn{2}{l}{ Experimental Class } & \multicolumn{2}{l}{ Control Class } \\
$1-100$ & F & F & - & - & - & - \\
\hline $96-100$ & A & Very good & - & - & - & - \\
$91-95$ & A- & & - & - & - & - \\
$86-90$ & B+ & & 1 & 6 & - & - \\
$81-85$ & B & Good & 2 & 12 & - & - \\
$75-80$ & B- & & 2 & 12 & 1 & 6 \\
$70-74$ & C+ & & 4 & 24 & 2 & 11 \\
$65-69$ & C & Fair & 1 & 6 & 4 & 22,22 \\
$60-69$ & C- & & 3 & 18 & 3 & 16,67 \\
$55-59$ & D+ & Poor & 4 & 24 & 8 & 44,44 \\
\hline 55 & D & & 17 & 100 & 18 & 100 \\
\hline
\end{tabular}

According to Table 2, there were improvements in the experimental and control class. The post-test was conducted twice after giving treatment for both classes to determine the validity of the test. The first post-test was given with the different pre-test, while the second post-test was given with the same pre-test text, then the result was valued by calculating the mean score of both post-test results. The experimental class used a translanguaging strategy, and the control class used a translation strategy to enhance reading comprehension. There are heterogeneous data from low to good classification appear in the table. The cause might be the time distance between the first post-test and the second post-test. Besides, the respondents had assigned the text of the second post-test at the first meeting. Despite the fact, there were improvements for both classes.

The Mean Scores difference between Experimental class and Control class

The mean score difference for both experimental and control class after calculating the result of pre-test and post-test presented as follows:

TABLE 3

STUDENTS' MEAN SCORE DIFFERENCE

\begin{tabular}{|l|l|l|l|}
\hline Class & Pre-test & Post-test & Mean difference \\
\hline Experimental & 27.64 & 61.17 & 33.52 \\
\hline Control & 37.22 & 53.61 & 16.38 \\
\hline
\end{tabular}

Table 3 shows the improvement of each class, where the experimental class and the control class had improvements in their study after giving some treatments. The mean difference of the experimental class had a higher different score to control class score. There was a 17.14 difference score between both classes. It shows that the reading comprehension of the experimental class and control class both enhanced. However, the experimental class had better improvement to control class.

According to the mean difference, the researchers inferred that translanguaging could enhance the reading comprehension of students.

The Standard Deviation in Pre-test and Post-test

The following table described the standard deviation of the experimental and control pre-test classes in both the preand post-test.

TABLE 4

The Standard Deviation Of StUdents In Pre-Test And Post-Test STANDARD DEVIATION

\begin{tabular}{|l|l|l|}
\hline Standard Deviation & Pre-test & Post-test \\
\hline Experimental & 12.51 & 11.25 \\
\hline Control & 9.58 & 9.36 \\
\hline
\end{tabular}


The standard deviation in Table 4 shows the pre-test had a higher standard deviation score rather than post-test. The pre-test had a higher value because there was still much variance in learning style. After giving some treatment, both classes had descended value in the post-test. Even both classes did not decrease significantly, but the variance of students' learning style decreased after the treatment. The result indicated that the treatment for both classes was not done maximally. However, the result shows that the standard deviation score was lower than before giving treatment..

Hypothesis Testing

The researchers used the t-test formula in the testing hypothesis. The level of significance was set $a=0,05$.

TABLE 5

The T-Test And T-Table VAlue In PRe-Test And Post-Test

\begin{tabular}{|l|l|l|}
\hline \multicolumn{2}{l}{ THE T-TEST AND T-TABLE VALUE IN PRE-TEST AND POST-TEST } \\
\hline Test & T-Test Value & T-Table Value \\
\hline Prest & -2.5503 & 2.042 \\
\hline
\end{tabular}

Table 5 shows the result of the calculated t-test. The t-table value was set $\mathrm{a}=0,05$ for a two-tail test with 2.042 significance, where the degree of freedom was 33. The t-test value of the pre-test was lower than the t table value, while the post-test t-test value was higher than the t-table value with small space. According to the research hypothesis, if the $\mathrm{t}$-test value was equal with the t-table value, the null hypothesis was accepted, and the alternative hypothesis was rejected. Meanwhile, if the t-test value was unequal with the t-table value, the null hypothesis (H0) was rejected, and the alternative hypothesis (H1) was accepted. After giving some treatment used translanguaging and translation, the alternative hypothesis (H1) was accepted, and the null hypothesis (H0) was rejected. The final result of hypothesis testing was that the mean score of the students who learned reading through translanguaging strategy in enhancing reading comprehension was unequal to the mean score of the students who learned reading through translation strategy to enhance reading comprehension. Therefore, the researchers inferred a significant difference in the students' reading comprehension of the eighth-grade students of SMP Negeri 4 Maiwa, who learned reading using the translanguaging strategy than the students who learned reading by using translation strategy.

\section{B. Discussion}

The translanguaging process was used during the task given and presentation. The researchers found that students were independently easy to answer and understand the text well by using translanguaging strategy, according to a significantly increasing task score. During the treatment, the experimental class could elaborate on their efforts more while doing the task given. Since the students did the tasks in a translanguaging strategy, they could actively share their understanding with other students. This in in line with the works of other researcher like Swanwick (2015) and Panda (2016) who suggested the use of this strategy in language teaching especially in teaching reading.

The Indonesian text with the English question, for instance, could facilitate them to find out the answer to the text. They only needed to find the English vocabulary to write down the result. Thus, students could share their reading experience and opinion related to the reading text in both languages using translanguaging strategy.

By using the limited technology, the students put the benefit of the school library to find any text to be learned using translanguaging strategy, then presented and wrote the content out in the English language or local language. The student seemed to be more understanding when they were presenting tasks in their mother tongue or local language. According to the last treatment, individual tasks showed that students could autonomously analyze the content of their reading text. The students understood when mother tongue language be used during the reading comprehension class to interpret the meaning, in order to achieve reading goals. Therefore, the translanguaging strategy is an effective solution to be used in the learning process. It can help the students to solve their learning obstacles (Grabe and Stoller, 2013). The students can practice the language by applying different features of language which against each other in one interaction (Gracia and Wei, 2014).

There was a different condition in the control class. The text and question given should be translated into the students' mother tongue or Indonesian firstly. The students used the word to word translation in this phase, because they had to lack English vocabularies. There were only a few students wanted to find the meaning in the dictionary. The reason was they were lazy to see lots of vocabulary to be translated, then answer the question also in the English language - this strategy, sometimes used by the other teacher during the English class. The researchers found that the translation strategy made students boring in the learning process. Students could not actively reproduce various kinds of text coming from translated words. The students always asked for the teacher's help to translate the text while they only tried to find a better answer for a good score.

The teacher applied the way by asking the basic knowledge of the students before reading. The text was in a narrative text. Hence some of the students had read or listened to the stories given. Students applied the translanguaging to explain their prior knowledge about the text during the reading process in the experimental class. Formerly, after reading the text, they easily answered the text based on their reading interpretation. The control class also interpreted their reading, but the student took too much time to understand the text. It was because they were inactive to translate all the text. As a consequence, the task could not be done in proper time allocation, and the text could not be understood maximally. However, the score tasks significantly increased for both classes. 
To assess the effects of four meetings for the treatment, the researchers conducted a post-test in each group. The first post-test was given with different text and questions to determine whether students could answer the different text. The result shows a different result, where the experimental class had a higher score than the control class. The score difference of the experimental class was higher, but the result could not be classified as a significant result. Therefore, the researchers drove to conduct the second post-test with the same reading material with the pre-test. After conducting the second post-test, both classes had a raising score. Based on the results of the first post-test and the second post-test, there was a more significant improvement in both classes. The improvement for both classes might cause the experimenter effect because the text for the second post-test had been taught through each class strategy. Things happened. The experimental class still had a higher score rather than a control class. The final result of hypothesis testing was the mean score of the students who were taught through translanguaging strategy in enhancing reading comprehension was unequal to the mean score of the students who were taught through translation strategy in enhancing reading comprehension. Therefore, the researchers inferred that there is a significant difference in the students' reading comprehension of the eighth-grade students of SMP Negeri 4 Maiwa, who were taught by using translanguaging strategy than those who were taught by using the translation strategy.

\section{CONCLUSION}

Based on the findings, the researchers then conclude that the use of a translanguaging strategy could enhance students' reading comprehension. It was proved that the use of translanguaging strategy in teaching reading comprehension of the eighth-grade student of SMP Negeri 4 Maiwa has a significant effect on enhancing students' reading comprehension.

Applying the $\mathrm{t}$-test formula for the students for both groups found that the $\mathrm{t}$-test was unequal with the $\mathrm{t}$ table, which means this translanguaging can be used to enhance student reading comprehension. The result also shows that the student means difference was different. From these data, the researchers concluded that translanguaging could improve students' reading comprehension by combining it with the other classroom strategy.

\section{REFERENCES}

[1] Ayeomoni, M. (2006). Code-Switching and Code-Mixing: Style of Language Use in Childhood in Yoruba Speech Community. Nordic Journal of African Studies, 15(1), 90-99.

[2] Baker, C. (2011). Foundations of Bilingual Education and Bilingualism (5th ed.). Bristol, UK: Multilingual Matters.

[3] Celic, C. (2012). Translanguaging: Strategies for the Classroom. In Translanguaging: Strategies for the Classroom (p. 30). New York: NYSIEB Seminar.

[4] Desmond, V., \& Makalela, P. L. (2013). The effects of translanguaging on the bi-literate inferencing strategies of fourth grade learners. Perspective in Education, 34(3), 86-97. Retrieved 18 Jan 2017 from org/10.18820/2519593X/pie. v34i3.7.

[5] García, O., \& Wei, L. (2014). Translanguaging: Language, Bilingualism and Education (1st ed.). United Kingdom: Palgrave macmillan. https://doi.org/10.1057/9781137385765.

[6] Gay, L. ., E. Mills, G., \& Airasian, P. (2011). Educational Research : Competencies for analysis and Applications (10th ed.). United States of America: PEARSON.

[7] Grabe, W., \& Stoller, F. L. (2013). Teaching and Researching Reading. (C. N. Candlin \& D. R. Hall, Eds.) (Second edi). London and New York: Routledge Taylor \& Franciis Group.

[8] Kemendikbud. (2016). Panduan Gerakan Literasi Sekolah Menengah Pertama. Jakarta: Kementrian Pendidikan dan Kebudayaan.

[9] Klingner, J. K., Vaughn, S., \& Boardman, A. (2015). Teaching Reading Comprehension to Students with Learning Difficulties. Retrieved 8 Feb 2017 from https://books.google.com/books?id=sjH2BQAAQBAJ\&pgis=1.

[10] Mateus, S. G. (2014). Translanguaging: Language, Bilingualism, and Education. Bilingual Research Journal, 37(3), $366-369$. https://doi.org/10.1080/15235882.2014.965361.

[11] Ordudari, M. (2010). Translation procedures , strategies and methods. Translation Journal. Retrieved 25 July 2017 from http://translationjournal.net/journal/41culture.htm.

[12] Panda, A. (2016). Translanguaging: A Pedagogical Tool to Improve Reading Comprehension of Learners in a Multilingual setting in Odisha. In International Conference on Language and Education: Sustainable Development through Multilingual Education 19-21 October 2016 (p. 2016).

[13] Park, M. S. (2012). Code-switching and Translanguaging: Potential Functions in Multilingual Classrooms. TESOL and Applied Linguistic, 13(2), 50-52.

[14] Snow Andrade, M. (2006). International students in English-speaking universities. Journal of Research in International Education, 5(2), 131-154. https://doi.org/10.1177/1475240906065589.

[15] Swanwick, R. (2015). Translanguaging as Scaffolding for Learning in Bilingual Bimodal Classromms Ruth Swanwick The School of Education, University of Leeds, 1-6.

[16] Sugiyono. (2016). Statistika Untuk Penelitian (27th ed.). Bandung: Alfabeta.

Rafi'ah Nur was born in Paddangeng Soppeng, Indonesia, on April 10th, 1969. She received the magister degree in English language study in 2001 from Universitas Hasanuddin, Makassar, Indonesia. Her doctoral degree was obtained in English language education in 2015 from Universitas Negeri Makassar, Indonesia. During her doctoral degree study, she got a chance to attend a 
Doctoral Sandwich-like Program awarded by the Ministry of Higher Education in September to December 2011 at Ohio State University.

She is a civil servant who is teaching at English Language Education at Universitas Muhammadiyah Parepare since 1994. She was the chief of the English Language Education Study Program. Currently, she is the assistant director of the Graduate Program of Universitas Muhammadiyah Parepare, Indonesia.

Dr. Nur has some professional memberships like Asia TEFL and TEFLON. She has published some articles in Scopus-indexed journals. The articles entitled "Designing an Instructional Model of YouTube-Based Materials of Listening Comprehension at Umpar Indonesia" and "Utilizing the Instagram Videos to Enhance the Students' Language Acquisition on Writing Composition" are two of her publications in the Scopus-indexed journals. Her research interests include curriculum and material development, language testing, and linguistics analysis.

Zulwahyuni Namrullah received a bachelor's degree in English Education from Universitas Muhammadiyah Parepare. During her study, she is a volunteer in many teaching activities until today, also the founder of Aksi Anak Belajar Bersama (AKSARA) as a street children's learning community. She is also active as a staff in International Relations and Affairs Universitas Muhammadiyah Parepare.

Syawal received his bachelor's and master's degrees in English Education at Universitas Muhammadiyah Parepare. He is currently teaching English at the university and awarding an LPDP scholarship to continue his Ph.D. degree at Universitas Negeri Makassar.

Nasrullah A received the bachelor's and master's degrees in English Education from Universitas Muhammadiyah Parepare. He is also a lecturer at Universitas Muhammadiyah Parepare. 